\title{
DEVELOPING ENGLISH MATERIALS FOR MILITARY CADETS
}

\author{
N. N. S. W. Puspitasari ${ }^{1}$, P. K. Nitiasih ${ }^{1}$, I. W. Suarnajaya ${ }^{2}$ \\ ${ }^{123}$ English Language Education, Post Graduate Program, Universitas Pendidikan Ganesha, Singaraja \\ e-mail: omingwahyu@gmail.com, kertinitiasih@undiksha.ac.id, wy.suarnajaya@undiksha.ac.id
}

This research was intended to find out the topics needed, develop new materials, and investigate the quality of the developed English materials for Military Cadets which will be used at Rindam IX Udayana, one of military base camps in Bali. The existing books used were lack of some aspects; layout and design and grammar points. As it answered those purposes mentioned previously, the design of this research was Research and Development proposed by Hannafin and Peck. The subjects of this research were soldiers and the object was the design of course materials. The procedures of developing the product were (1) Need Assessment-evaluation and revision, (2) Design-evaluation and revision and (3) Development/Implementation-evaluation and revision. Based on the procedures being followed, it is found that the subjects needed ten topics namely greeting, introduction, communicating by phone, sports and fitness, requesting and commanding, asking and giving help, surviving by enough supply, giving briefing in war games, asking for and giving direction, and taking transportations. Further, the quality of the developed textbook is good; this was proven by expert judges. In addition, the findings of this research are useful for military cadets, instructor, and institution itself.

\section{Keywords: English materials, military cadets.}

\section{INTRODUCTION}

English has been spoken by most people of the world. Reddy (2016) states there are 7 major roles of English language, comprising; business, education and specialized education, better job and salaries, easy access toward information, media and entertainment, official communication, and international relations maintenance. Thus, regarding to the concept of various uses of English, the expansion of this language to countries in the world has brought a new wave to educational world. The teaching of English has been divided into two; the teaching of general English and the teaching of English for Specific Purpose (ESP). ESP is an approach to language teaching where all decisions as to content and method are based on the learners' reason for learning (Hutchinson and Waters, 1987). It covers different aspects of humans' life, such as business, tourism, military, nursery, etc. Further, the ESP includes more than the teaching of English through special materials and content. It combines linguistics skill together with the acquisition of special information (Khan, 2011). Additionally, he states that every single group of students and professionals have distinct learning needs. The appropriate pedagogy taking into account in the learner's teaching and learning. Shortly, ESP is studentsdirected course which prepares them for particular environments. The focus is on students' skills not the subject matter.

The English language has become the language of choice for the military cadets worldwide. Communicating in English is essential for them who participate in international organizations, in peacekeeping operations and taking part in various trainings abroad. Moreover, Indonesian Armed Forces (Tentara Nasional Indonesia/TNI) is open to cooperate with international partners worldwide since Indonesia joined Association of South East Asia Nations (ASEAN) and United Nations (Perserikatan Bangsa-bangsa/PBB). Therefore, the mastery of English becomes one of the top priorities. The teaching of English in the military uses the ESP approach since military English has its own vocabularies, acronyms and idioms. Further, the military cadets have different learning needs and interests.

The teaching of ESP in the military academy is more difficult. Jodai (2012) states that many English instructors in the military rely too much on the textbooks available. They remotely able to evaluate their suitability based on personal experience, and unwilling to do the necessary analysis of difficult specialist texts to verify their contents. Furthermore, based on a 
prior interview that researcher had done to one English instructor at Rindam IX Udayana, there are three main problems why his students cannot speak English properly. Those are English speaking is not included on entrance examination, they are taught for the sake of examination, and the class is often too big to handle. Additionally, it was found that the existing textbooks used have some issues, such as the pictures are pitching black, the vocabularies are not repeated, some of the language instructions are not clear and understandable, and the activities are monotonous. Those issues surely make students uncomfortable in learning. Moreover, it violates Tomlinson's (2009) principle of effective materials. Regarding to those rationale, this research aimed at developing ESP materials for cadets. It was designed to be appropriate with their future tasks. By having the new materials, hopefully the cadets could get meaningful knowledge and acquire useful skills.

This research was conducted to develop ESP materials for teaching English for Military Cadets in Rindam/Udayana IX. In developing the new ESP materials, it is important to analyze the needs of the students in learning certain language. It will help researcher figuring out what is necessary or what should be avoided. This research was grounded by Hutchinson and Waters' (1987) framework of need analysis, specifically Target Situation Analysis (TSA) and Present Situation Analysis (PSA). TSA is a type of needs analysis in which it is digging about students' necessities of learning certain thing (e.g. English language). Meanwhile, PSA is a needs analysis where researcher seeks for subjects' strengths and weaknesses toward certain thing (e.g. English mastery). Moreover, Robinson's in Susanta (2016) techniques were used to gather those needs to develop the new materials. Further, the development of the new product was guided by Tomlinson's (2009) framework of developing good materials and also Widodo and Pusporini's (2010) framework of developing effective ESP materials.

Widodo and Pusporini (2010) state that the ESP materials should cover several aspects. First, it should have a clear set of learning goals and objectives. Second, it should contain learning tasks which allow for students' schemata or background knowledge and experience activation. Third, the learning tasks in the materials should allow students to explore their specialized needs and interest. Fourth, it should enable students to develop their language skills for authentic communication and content competence. Fifth, it should integrate language skills emphasized. Lastly, it should have impact on learners' development.

After the needs analyses were analyzed, they were then developed into new textbook by using Hutchinson and Waters' (1987) ESP design model. It includes input, content focus, language focus and tasks. The new materials were evaluated by using Litz's (2005) checklists in which those points in his work represent Tomlinson's (2009) framework of good materials.

\section{RESEARCH METHOD}

This is an R\&D research that grounded by Hannafin and Peck's (2014) framework. There are three major phases on this research, encompassing Need Assessments-evaluation and revision, Design-evaluation and revision, and Development/Implementation-evaluation and revision. Briefly speaking, the first step to be experienced on this model is 'need assessment' in which identifying what might be the problem on the existing textbooks and teaching and learning. Then, the next step is 'design' which begins with determining the objectives, topic and activities. Lastly is the development/implementation step. All those main steps were evaluated and produced any revision.

The subjects of this research were the cadets (kelas intensif bahasa Inggris also known as Kibi) who were studying English course for about four months. There were 20 students, 1 English instructor, and 1 stakeholder participated in this research; they are mostly males. They are mostly 21 to 30 years old. The educational background of them were mostly lower than bachelor degree and one of the participants was bachelor degree. They mostly had been working in the military for about less than 5 years. According to one instructor there, these cadets were not really good at English listening, speaking, reading and writing. This might be because they could not connect the lesson into their everyday life, which is why they were being a little ignorant on this course. 
According to Robinson in Susanta (2016), there are several instruments that can be used to gain data. Those instruments are questionnaire, interview guide, case studies, observation sheets, test, authentic data collection, and participatory need analysis. This research used researcher-completed instruments and subject-completed instruments namely observation sheet, questionnaire, interview guide, and scoring rubric for the document analysis.

Observation was done as the first step of gathering students' needs. It was conducted by the assistance of observation sheet. There were five points in the observation sheet, such as (1) are the students active during the learning process when using the existing book?, (2) do the students willing to answer the activities in the existing book?, (3) do the students understand the content and instruction of the existing book?, (4) do the activities related to the materials given make students happy and enjoy while using the existing book?, (5) do they usually ask something that they do not understand while using the existing book?

Questionnaire is a data collection instrument which consists of series of questions and other prompts for the purpose of gathering information from respondents. The researcher used questionnaires for different respondents. The first questionnaire was given to lecturer of Kibi class in order to identify the target situation and the existing materials. Meanwhile, the second questionnaire was given to cadets for the same purpose as the first one. The last respondent was stakeholder who was familiar with military life and how English was used. This instrument was arranged by adapting Mohammadzadeh et. al. (2015) framework, Hutchinson and Waters' (1987) framework, Munir' (2013), and Litz' (2005). The questionnaire includes four parts, namely the background of data, the need of the topics, the general needs for cadets and openended questions in which they represent the demand topics besides the available topics.

An interview guide is very useful in this research. It is used to gain any additional information to support the existing data from the previous instrument. Furthermore, a document analysis is a must on this research. According to Robinson (2016), any authentic data analysis is one of the techniques for need analysis (need assessment). In this case, the authentic data analysis was done to printed materials, such as existing syllabus, existing textbook.

The scoring rubric is used for evaluation. This instrument gave some information about the quality of the developed materials. Since the quality of the developed materials cannot be judged by the researcher or developer to avoid bias or subjective evaluation, it was handed out to two expert judges and lecturer of Rindam IX Udayana. The results of the evaluation from these judges were very helpful to complement the developed materials.

The gathered data should be analyzed. The gained data in this research were analyzed in two ways; qualitatively and quantitatively. The qualitative ones were analyzed by using Miles and Hubberman' methods in which they cover; data reduction, data display, and conclusion. On another hand, the quantitative data were analyzed by using Gregory formula in order to test the content validity. The data reduction was done to classify some data that can support the development of the research and the unnecessary ones. Those beneficial data were displayed to find the precise pattern. It could be in the form of charts, graphs, tables, and so forth. These exact patterns were used to draw any conclusion and they should be verified to investigate the validity and reliability.

Table 1. Gregory Formula (2000)

\begin{tabular}{|l|l|}
\hline $\mathrm{D}(+,+)$ & A (-,-) \\
\hline C (-,+) & B (+,-) \\
\hline
\end{tabular}

Table 2. Candiasa's Formula (2010)

Content Validity $=\frac{D}{(A+B+C+D)}$




\begin{tabular}{lc}
\hline \multicolumn{1}{c}{ Score } & Criteria \\
\hline $\mathrm{X} \geq \mathrm{M} i+1.5 \mathrm{Sd} i$ & Excellent \\
\hline $\mathrm{M} i+0.5 \mathrm{Sd} i \leq \overline{\mathrm{X}}<$ & Good \\
$\mathrm{M} i+1.5 \mathrm{Sd} i$ & \\
$\mathrm{M} i-0.5 \mathrm{Sd} i \leq \overline{\mathrm{X}}<$ & Average \\
$\mathrm{M} i+0.5 \mathrm{Sd} i$ & \\
\hline $\mathrm{M} i-1.5 \mathrm{Sd} i \leq \overline{\mathrm{X}}<\mathrm{M} i$ & Below Average \\
$-0.5 \mathrm{Sd} i$ & \\
\hline$\overline{\mathrm{X}}<\mathrm{M} i-1.5 \mathrm{Sd} i$ & Poor \\
\hline
\end{tabular}

$\mathrm{Mi}=1 / 2$ (ideal maximum score + ideal minimum score)

$\mathrm{SD} i=1 / 3(\mathrm{M} i)$

$M i=$ the ideal mean

$\mathrm{SD} i=$ the standard of deviation

$\mathrm{X}=$ the score of the experts

In addition, Cadiasa's formula were used to calculate the result of scoring rubrics handed out to expert judges.

\section{FINDINGS AND DISCUSSION}

There are two major findings in this research. They are the topics needed to be developed and how to develop them and the quality of the new product. Those topics were determined based on the data gathered through observation, interview, questionnaire, and document analysis which also known as Needs Assessment. The topics/units on the new textbook were determined and created through several steps as mentioned earlier. They were Need assessments, Design, and development/implementation. Each of the step were evaluated and produced revision. In accordance to the results of Need assessments, there are several characteristics of the developed textbook, such as; (1) the materials should cover four skills, (2) the topic should specifically discuss about military life, (3) the materials should introduce learners with real life communication, (4) the materials should contain some language expressions, (5) the activities or tasks on the developed materials should be varied, (6) the activities should be appropriate to students' level, (7) the materials should provide pictures, and (8) the materials should provide some vocabularies. Here are some results of needs assessment from questionnaire;

Table 3. Generals Needs

\begin{tabular}{lcc}
\hline Descriptions & Agree (\%) & $\begin{array}{c}\text { Disagree } \\
(\%)\end{array}$ \\
\hline for study & 98 & 2 \\
\hline for work & 87 & 13 \\
\hline for training & 87 & 13 \\
\hline in speaking & 91 & 9 \\
\hline in writing & 91 & 9 \\
\hline in reading & 91 & 9 \\
\hline $\begin{array}{l}\text { face to face } \\
\text { interaction }\end{array}$ & 91 & 9 \\
\hline $\begin{array}{l}\text { on the } \\
\text { telephone }\end{array}$ & 87 & 13 \\
\hline $\begin{array}{l}\text { in formal } \\
\text { situation }\end{array}$ & 83 & 17 \\
\hline $\begin{array}{l}\text { in informal } \\
\text { situation }\end{array}$ & 83 & 17 \\
\hline $\begin{array}{l}\text { Native } \\
\text { speaker }\end{array}$ & 83 & 17 \\
\hline $\begin{array}{l}\text { Working } \\
\text { partners }\end{array}$ & 87 & 13 \\
\hline
\end{tabular}




\begin{tabular}{lcc}
\hline $\begin{array}{l}\text { in the base } \\
\text { camp }\end{array}$ & 91 & 9 \\
\hline abroad & 83 & 17 \\
\hline currently & 91 & 9 \\
\hline $\begin{array}{l}\text { after the } \\
\text { course }\end{array}$ & 91 & 9 \\
\hline
\end{tabular}

This table presents about how important the use of English language in the military is. Further, it represents about context, English language participants, areas where the military force use English, and the time when the military force use English.

Table 4. Cadet's English mastery

\begin{tabular}{lcccc}
\hline $\begin{array}{l}\text { Language } \\
\text { Skills }\end{array}$ & $\begin{array}{c}\text { Very } \\
\text { Good } \\
(\%)\end{array}$ & $\begin{array}{c}\text { Good } \\
(\%)\end{array}$ & $\begin{array}{c}\text { Ade } \\
\text { quate } \\
(\%)\end{array}$ & $\begin{array}{c}\text { Weak } \\
(\%)\end{array}$ \\
\hline Grammar & 0 & 16 & 47 & 37 \\
\hline Vocabulary & 0 & 11 & 47 & 42 \\
\hline $\begin{array}{l}\text { Pronuncia } \\
\text { tion }\end{array}$ & 0 & 16 & 42 & 42 \\
\hline Listening & 0 & 11 & 58 & 32 \\
\hline Reading & 5 & 32 & 53 & 11 \\
\hline Speaking & 0 & 21 & 37 & 42 \\
\hline Writing & 5 & 16 & 37 & 42 \\
\hline
\end{tabular}

Based on the table above, the military cadets in Rindam IX Udayana believed that English mastery has significant role on their military life; however, they seemed not really confident in it. It is due to several reasons; they thought that they have an adequate knowledge of English grammar, they did not have enough military English vocabularies, and they did not pronounce things perfectly. They also believed that their English listening, reading, speaking and writing skill is on adequate level and they considered it as almost weak. The lacks of their English ability might have been influenced by several reasons; one of them is the current English course books. Here is the quality of the current books that were evaluated from several criteria, such us vocabulary, content, language type and instruction problem.

In accordance to the development process of making the textbook including need analysis, design, and develop, the developed textbook for Military Cadets finally contains ten units. Those are (1) Greeting, (2) Introduction, (3) Communicating by Phone, (4) Sports and Fitness, (5) Requesting and Commanding in the Military, (6) Asking and Giving Help, (7) Surviving by Enough supply, (8) Giving Briefing in War Games (9) Asking for and Giving Direction, and (10) Taking Transportations. Soldiers should have good knowledge of greeting people as senior-junior relationship play crucial role in the military. They are likely establishing relationship with co-workers, foreigner, or society around them. They expected to be able handling incoming and outgoing call in proper manner. Having a fit and healthy body is another crucial point of being military men/women, thus they learn about sport and fitness. They also expected to be able to make proper request and command especially when it comes to seniorjunior bearing. Further, they should also have knowledge about giving and responding to briefing in war game since they would encounter them a lot to improve their tactical skill. As they get war games, they could possibly get the real war and surviving by enough supply is important. Moreover, shoulders are required to go abroad to meet their training or war. The countries they are visited is often use English as native language/lingua franca, therefore learning some basic communication with the local like asking and giving direction or help and taking transportation is worthwhile.

The developed textbook consists of four language skills, specifically listening, reading, speaking, and writing. The listening activities were taken / adapted from credible sources and self-created as Litz (2005) states in his work 'the textbook's activities can be modified and 
supplemented easily'. However, the audio was self-created by the assistance of Natural Reader 14 Professional Scicrack. This application was being trusted due to the fact that it is a brilliant app. This was proven by a research conducted by Suryani (2018); she developed listening materials for junior high school students in which the activities were produced from this app. It was called brilliant because it produced clear and non-robotic voice and the user could choose both male and female voice. The reading text/content focus was taken from the internet and military textbooks, but the tasks were self-produced or adapted. Those tasks were created to explore the students' comprehension and enrich their vocabularies. Thus, this developed textbook provided vocabulary corner to help them. The speaking activities were self-produced and adapted. They were in the form of role playing; the tasks were either dialogues or monologues. The students were provided with so many conversations based on the reason that it could give real-life context. Some writing activities appeared on the textbook were integrated with speaking activities. Therefore, the tasks were quite similar. The developed textbook covered four language skills as Tomlinson (2009) explains in his principles of SLA relevant to materials development in language teaching, students can get the exposure through spoken and written text included in the materials. The listening helps them to know English by listen to it first, afterward followed by practice using it, and seeking information more about it by reading and finally able to produce written language. Litz (2005) states the textbook includes a detailed overview of functions, and vocabulary that will be taught in each unit. Tomlinson (2009) agrees that learners should be directed to linguistic features of the input. He explains that by knowing the gap and similarities between their target language and explanation that were given through quiz, they can understand and use the features well in the target language. The developed textbook did provide an overview in each unit explaining about topic students would learn and objectives they should achieve. Further, it provided language expressions and vocabulary section. In addition, those language expressions were completed by some explanations on how they can be used in a conversation. Meanwhile, the vocabularies presented on the textbook were being learnt through whole class activities and individual work.

Tomlinson (2009) states the materials that are used in teaching and learning process should give noticeable impact to students. This notion is also supported by Widodo and Pusporini (2010) in their framework of developing ESP materials. The developed textbook had fulfilled this since it presented various activities which can pull out students' curiosity and attention toward learning military English. It provided variety and attractive illustrations too. Further, those activities were able to encourage and help them to feel at ease since they were challenging for the lower level students and obviously achievable for the high level students.

The activities provided on the developed textbook were authentic and gave students the opportunities to use the target language to achieve communication purpose. It was concluded like that since they were mostly in the form of role play (conversation). Richards (2005) believes that the learners can learn when they can engage in interactive and meaningful communication and role play provides it. In addition, the expressions appeared on the conversation was already explained and being learnt on Language Focus section. Those expressions explained were often used in military context, such as giving briefing, drill commands, etc. This should fulfill Tomlinson's (2009) and Widodo and Pusporini's (2010) principle of developing good materials.

The developer took into account that students were differ in language learning styles and attitudes toward learning. Therefore, she developed the materials contained with not only long passages, but pictures, audio, and kinesthetic activity (e.g. drill command). This point had fulfilled Tomlinson's (2009) principle too.

In terms of layout and design, criteria from Litz (2005) were taken into consideration. It consists of (1) whether or not the textbook is attractive, (2) whether or not it provides adequate vocabulary list, (3) whether or not it provides exercise and evaluation and (4) whether or not it provides clear objective and appropriate guidance. The developed textbook was considered relevant to those criteria, as it proven by expert judges, even though there were some revisions on the vocabulary section.

Furthermore, the language type of the military English textbook was considered relevant by the experts too. The criteria were taken from Tomlinson's (2009), Widodo and Pusporini's 
(2010) principles and Litz (2005) checklist, such as (1) the materials is authentic, (2) the language is according to students' current English ability and (3) progression of grammar, vocabulary, and language function is easy to understand. Even though, it was considered relevant, but it still produced some revision especially on the grammar point. In terms of content, the developed textbook was considered relevant to the students' need since it provided various topics that could get them closer to real life situation. It was also realistic and challenging but motivating. This had been proven by the expert judges.

In short, the developed materials had already fulfilled some principles of good ESP materials as stated by Tomlinson (2009), Litz (2005), and Widodo Pusporini (2010). Moreover, in accordance to the expert judgments, the developed textbook was categorized as good materials. The results of evaluation were calculated from Candiasa's formula. The score was 373.

\section{CONCLUSION AND SUGGESTIONS}

The development of the materials was guided by Research and Development design proposes by Hannafin and Peck (2014). The research began from identifying the problem happened which were gathered from observation, questionnaire, interview and document analysis. It was found that the cadets in Rindam IX Udayana needed the supplementary materials. In accordance to the needs assessment, the topics were designed and developed by determining the objectives, input, text, vocabularies, language features, and activities. Besides, a proper application like Microsoft Word, Microsoft Excel, Natural Reader 14, and Hot Potato was being used too. Afterward, those steps from need assessment, design, and development were evaluated and produced revisions. Referring to these processes, the ESP materials needed in this research had been found. There were 10 units needed by soldiers. The exercises of those topics were varied. Moreover, based on the expert judgments, the new materials belong to good materials. This category was taken from calculating Candiasa's formula. The materials score is 373.

There are some suggestions that can be given to some parties in relation to this research, namely other researchers and military English instructors. This research produced new military English materials. They were evaluated through expert's judgments. This research was limited with no actual implementation. Therefore, the implementation/ field test of the developed textbook would give major information about whether or not they are effective to be used by the military cadets. In addition, it could give benefit to soldiers, English instructor and the institution itself. Regarding to the experts' judgment, the developed textbook was considered as good materials. It is suggested that the military English instructors could use these materials in their class to support students' communicative skills. The materials can also be modified and supplementary easily.

\section{REFERENCES}

Candiasa, I.M.( 2010). Statistik Univariant dan Bivariant Disertasi Aplikasi SPSS. Unit Penerbitan Universitas Pendidikan Ganesha: Singaraja.

Gregory, J. (2000). Psychological Testing, History, Principles and Applications. Boston: Allyn and Bacon.

Hannafin, M.J. \& Peck, L.L. (2014). The Design Development and Evaluation of Instructional Software. In M.Tegeh, I.N.Jampel, \& K. Pudjawan. Model Penelitian Pengembangan. Jogjakarta: Graha IImu.

Hutchinson, T. \& Waters, A. (1987). English for Specific Purposes: A Learner-Centered Approached. Cambridge: Cambridge University Press.

Jodai, H. (2012). Evaluation of Worldview Textbook: Textbooks Taught at a Military University. International J. Soc.Sci. \&Education, Vol. 3, Issue 1

Khan, B. (2011). The Importance of ESP in Bangladesh. East West University. 
Litz, D. (2005). Textbook Evaluation and ELT Management: A South Korean Case Study. Asian EFL Journal. Retrieved from http://docslide.us/documents/litz-thesis.html.

Mohammadzadeh, S., Tahereh, B. \& Mohammad, F. (2015). An Investigation into the English Language Needs of Bank Employees of Saderat Bank in Mashhad. Theory and Practice in Language Studies, Vol. 5, No. 8, pp. 1695-1702.

Mukundan, J. Nimehchisalem, V., \& Hajimohammadi, R. (2011). Developing an Englaih Language Textbook Evaluation Checklist: A Focus Group. International Journal of Humanities and Social Science, Vol. 1, No. 12.

Richards, J. (2005). Materials Development and Research-Making the Connection. Retrieved from https://www.researchgate.net/publication/238548288 Materials Development and Rese arch--Making the Connection.

Reddy, M.S. (2016). Importance of English Language in today's World. International Journal of Academic Research, Vol. 3, Issue-4(2).

Suryani, L.P., Artini, L.P., \& Putra, I.N.A. (2018). Developing English Supplementary Local Wisdom Based Listening Materials Based on Curriculum 2013 Using Natural Reader 14 Application for Eight Grade Students at SMP Negeri 2 Singaraja. Ganesha University of Education.

Susanta, I.P.E., Nitiasih, P.K., \& Budasi, I.G. (2016). Developing English Course Materials for Paramedics. Ganesha University of Education.

Tomlinson, B. (2009). Materials Development in Language Teaching (Ed.). UK: Cambridge University Press.

Widodo, P. \& Pusporini, R. (2010). Materials Design: English for Specific Purposes (ESP). ELT Journal, 37(3), 251-255 